repeated scenes such as I will now attempt to describe to you. In this ideal picture I have endeavoured to depict what I consider to have been the state of things. Here we have the valley of the river some six or seven miles broad. The streams reduced to streamlets meandering through dried and barren sand-banks. Among them are more elevated patches-islands, if we may use the term islands standing up from the general expanse of sand, and in some cases actual islands in the sense that they were surrounded by water. Here and there pools of water, some almost stagnant, others fed by minute streamlets.

Looking at the scene from a southern standpoint we should see to the north the distant chalk range. Whilst along the shore of the opposite bank of the valley we could with some difficulty detect the various forms of vegetation, which we should see with greater clearness in the more immediate foreground. In this valley a singular stillness must have prevailed, as no trace of animal life whatever has been found, except a feather and a few insect wings blown in from the southern bank.

Of the following at least we are pretty sure, and of numerous others we can be almost sure, but there are indications of very many besides, the relationships of which are at present but imperfectly defined.

Here we should see the graceful fan-palm and the feather palms, adding softness to the view by their elegantly-curved and drooping leaves, laurel and dwarfed oak, stately beeches, clumps of feathery acacia, trellised and festooned with smilax, the trailing aroid, with its large and glossy foliage and an undergrowth of Mimosa and of cypress in the swampier ground, and variations in colour caused by the foliage of cinnamon and fig, and the ground clothed with ferns and sedges. On the barren sands of the distant valley are growing clumps of giant and weird-looking cactus. It is not difficult to picture to ourselves the view. (See Fig. 2.)

All this beauty is gone. We have nothing but these records of what must have been a view of great loveliness, which only the toil of the geologist can even faintly reproduce.

"The hills are shadows, and they flow

From form to form, and mothing stands;

They melt like mist, the solid lands,

Like clouds they shape themselves and go.

"There rolls the deep where grew the tree.

O Earth, what changes hast thou seen!

There where the loog street roars, hath been

The stillness of the central sea"

\section{THE REPORT ON THE AUSTRIAN "NOVARA" EXPEDITION}

A FWW days ago Admiral v. Wüllerstorff Urbair, late A Commander-in-Chief of the Austrian Novara Exploring Expedition, had an audience of the Emperor to present to his Majesty the final report on the scientific results of this great exploring cruise round tine world. It has required about seventeen years' serious labour, and has cost nearly $\mathrm{I} 3,000 \mathrm{l}$. sterling to complete this important scientific work, embracing 18 vols. 4 to. and 3 vols. 8 vo., and containing the anthropological, botanical, geological, zoological, physico-nautical, statistico-commercial, medical, and descriptive parts.

The narrative of the expedition, written by Dr. Karl von Scherzer (an author also well known in England, and at present attached to the Austro-Hungarian Embassy in London), has mes with such a success that five editions have been published and more than 29,000 copies sold.

The most interesting of the purely scientific publications is the geological "part, by Dr. Hochstetter, which gives the most complete description of the geology of New Zealand, the author having been the first naturalist who thoroughly explored these antipodean islands, and he has carefully examined and described its gold and coal deposits. The statistico-commercial part, by Dr. Karl von Scherzer, has become quite a standard book on the Continent.

The price of the complete series being very high (39r florins, or nearly $40 l$. sterling), the Emperor has given permission that a considerable number of copies of this most valuable publication should be given away to public institutions and libraries in the empire, as well as in foreign countries, and as the Novara has met with a particularly kind reception in the British colonies, the libraries of these have been considered first in the list of recipients of this great national work, which is a monument of scientific investigation.

\section{THE CYCLONE WAVE IN BENGAL}

$A N$ interesting correspondence on this subject has apA peared in the Times during the last few days, evincing generally on the part of the correspondents an earnest effort to arouse the public mind to a sense of the necessity of something being done towards mitigating the calamitous results of such occurrences in the future. The subject being one that must sooner or later be faced, it is beside the question to point to the destructive flooding of the Thames as a proof that the Government of India does not differ greatly in such matters from similar authorities at home.

As regards the meteorology of this important question, three lines of inquiry stand prominently out as calling for special and extended investigation. The first of these is a thorough discussion of the storms of the Bay of Bengal, or a continuation of the work under this head which has been ably begun by Mr. Blanford and Mr. Willson. The second line of inquiry is the cause or causes which originate the cyclone wave and determine the course it takes-a subject on which we cannot be said to have any information at present, all that is or can be said being little more than unsatisfactory conjectures. To carry out these inquiries with the fulness and with the detail required to ensure a successful handling of the subject additional stations must be established and the taking of meteorological observations must be more extensively and frequently done than is now the practice on board the ships which navigate the Bay.

The third line of inquiry is the systematic inauguration of a meteorological survey of the Bay of Bengal and its shores, with a more strict reference to its storms, by having first-class meteorological stations established at Trincomalee, Madras, Vizagapatam, False Point, Saugor Island, Chittagong, Akyab, Cape Negrais, the Andaman and the Nicobar Islands, these stations having a full equipment of instruments, including in each case a continuously registering barometer and anemometer. With these instruments the law of the diurnal oscillation of the barometer and of the changes in the direction and velocity of the wind, including the variations with season, would become known, and any deviation therefrom which may happen to occur, could be telegraphed at once to the head office at Calcutta. It may be regarded as absolutely certain, that no long time would elapse before the nature of the disturbing force, cyclonic or otherwise, revealed by the anomalous readings of the barometer and anemometer would come to be correctly interpreted; and with the aid of frequent telegrams from the whole circuit of stations, so well interpreted that the superintendent at Calcutta would have no difficulty in localising the cyclone, its track and rate of progress would be so certainly known that warning could be sent to the coasts threatened by it.

This system of storm warnings must not be confounded with that practised in Great Britain, in which no refined system of observations is called into play, and in which no accurate knowledge of mean periodic changes is required. What is chiefly required in this country is a 